PIOTR TOMCZYK (Poznań)

\title{
Podstawy praw człowieka w Deklaracji Praw Wirginii w świetle myśli Johna Locke'a
}

I. W historii praw człowieka Deklaracja Praw Wirginii z 1776 r. zajmuje szczególne miejsce. Jest to pierwszy dokument konstytucyjny, kodyfikujący uprawnienia przysługujące każdemu człowiekowi z samej racji bycia istotą ludzką. W akcie tym dokonuje się przejście praw człowieka ze sfery myśli i idei do sfery konstytuującej ustrój państwowy.

Pierwsze zdanie art. 1 Deklaracji Praw Wirginii brzmi: „Wszyscy ludzie są z natury równo wolni i niezależni i posiadają pewne przyrodzone prawa, których, kiedy przyjmują status społeczeństwa, nie mogą pozbawić swojej potomności przez jakąkolwiek umowę"1.

Fragment ten zawiera cztery podstawy praw człowieka. Są to założenia, których uwzględnienie jest niezbędne przy formułowaniu poszczególnych praw człowieka. Do podstaw należą przyrodzoność, równość, niezbywalność i uniwersalność praw człowieka. Celem niniejszego artykułu jest zbadanie powiązań podstaw praw człowieka, zawartych w pierwszym półzdaniu, pierwszego artykułu Deklaracji z chrześcijańskimi koncepcjami w myśli Johna Locke'a (1632-1704).

Punktem wyjścia analizy winno być przedstawienie głównych różnic pomiędzy Deklaracją Praw Wirginii i wcześniejszą, angielską Deklaracją Praw

1 ,All men are by nature equally free and independent and have certain inherent rights, of which, when they enter into a state of society, they cannot, by any compact, deprive or divest their posterity (...)". Przytoczony fragment Deklaracji Praw Wirginii, w polskim przełożeniu, znajduje się [w:] Z. Kędzia, Prawa i Obowiązki Obywateli, wybór źródeł, Wrocław 1978, s. 7; oraz K. Motyka, Prawa Człowieka, Wprowadzenie, Wybór Źródeł, Lublin 2004, s. 113. K. Motyka przejmuje tłumaczenie Deklaracji od Z. Kędzi. Z. Kędzia nadaje dokumentowi tytuł „Karta Praw Wirginii”. Oba pojęcia: „deklaracja” i „karta”, względnie declaration i bill, są poprawne i powszechnie stosowane. Autor skłania się ku stosowaniu terminu „deklaracja”, gdyż jest on używany przez George'a Masona i komitet redakcyjny w „Journal of the Virginia Convention”, informującym opinię publiczną o przebiegu prac nad Deklaracją. Zobacz: The Roots of The Bill of Rights, An illustrated Source Book of American Freedom, Volume 2, wyd. B. Schwartz, Ch. House Publishers, New York 1980, s. 236 n. 
z 1689 r. Elementem łączącym treść pierwszego półzdania z Locke’em jest autor Deklaracji Praw Wirginii, George Mason (1725-1792). Przyjrzenie się jego religijnym przekonaniom może być pomocne w zrozumieniu jego nastawienia do możliwej teistycznej interpretacji podstaw. Następnym krokiem będzie zbadanie zależności czterech wymienionych podstaw od chrześcijańskich idei w myśli Locke'a.

II. Deklaracja Praw Wirginii, uchwalona 12 czerwca 1776 r., jest nie tylko dokumentem przełomowym w historii praw człowieka, lecz miała także istotne znaczenie dla genezy Stanów Zjednoczonych Ameryki. Z jednej strony kończy ona proces polegający na stopniowej zmianie samoświadomości kolonii brytyjskich Ameryki Północnej, które jeszcze kilkanaście lat przed uchwaleniem deklaracji postrzegały siebie z dumą jako część Imperium Brytyjskiego, a swoich mieszkańców jako podmioty prawa brytyjskiego. Zmiany zaczęły następować po wojnie siedmioletniej, wraz ze zmianą ukierunkowania ustawodawstwa parlamentu angielskiego dotyczącego spraw kolonii. Wojna siedmioletnia ekonomicznie osłabiła metropolię. W celu uzupełnienia budżetu, parlament uchwalał ustawy obciążające kolonie. Obciążenia te polegały przede wszystkim na nakładaniu nowych podatków. Zaczęto sprzeciwiać się nieograniczonemu podleganiu legislacji brytyjskiego parlamentu, aż w końcu w czasie uchwalania deklaracji Wirginii zakwestionowano ostatni bastion stojący na drodze do niepodległości, czyli zwierzchnictwo Jerzego III (1738-1820) nad koloniami Ameryki Północnej.

Deklaracja była pierwszym z kilkunastu konstytucyjnych aktów prawnych, uchwalanych na przełomie lat 1776-1787, sankcjonowała ona niezależność od Anglii i konstytuowała nowy ustrój polityczny.

Porównanie jej genezy z Deklaracją Praw z 1689 r. uwidacznia ich odmienny charakter. Ta ostatnia była wynikiem pertraktacji parlamentu z Wilhelmem Orańskim (1650-1702) i jego małżonką z rodu Stuartów, Marią (1662-1694). Po ucieczce ojca Marii, Jakuba II (1633-1701), kwestia legitymacji Wilhelma jako następcy tronu była podważana. Torysi w większości utrzymywali, iż monarcha jest intronizowany przez samego Boga i jakiekolwiek działanie przeciw prawowitemu władcy byłoby grzechem ${ }^{2}$. Według ich przekonania Jakub II, mimo ucieczki, wciąż był prawowitym królem Anglii ${ }^{3}$. Wigowie również twierdzili, że prawowitemu władcy należy się posłuszeństwo ludu, lecz gdy jego decyzje skierowane są przeciwko interesom społeczeństwa, wówczas jego legitymizacja wygasa i można go w ostateczności nawet detronizować ${ }^{4}$. Przykładem rządzenia contra populum była polityka Jakuba II, który,

${ }^{2}$ G.E. Aylmer, 1603-1689, The Struggle for the Constitution, England in the Seventeenth Century, Blandford Press, London 1963, s. 209.

3 Ibidem, s. 210.

${ }^{4}$ Ibidem, s. 209. 
nie tylko w mniemaniu Wigów, w perspektywie długoterminowej dążył do katolicyzacji Anglii ${ }^{5}$. W zamian za zatwierdzenie Deklaracji Praw parlament uznał ucieczkę Jakuba za abdykację i zaoferował tron Wilhelmowi i Marii.

Deklaracja Praw Wirginii była natomiast deklaracją ,,dobrego ludu Wirginii”6, ogłaszającego „podstawę i fundament rządu”. Miała być instrumentem ograniczającym legislaturę w zakresie stanowienia przez nią prawa. Ograniczenie polegało na zakazie naruszania uprawnień ustanowionych w Deklaracji ${ }^{8}$. Uprawnień obejmujących każdego człowieka, nie tylko mieszkańców Wirginii.

Angielska Deklaracja, podobnie jak Deklaracja Praw Wirginii, zawierała listę uprawnień. Adresatem tych uprawnień nie był jednak, tak jak w Wirginii, każdy człowiek, lecz jedynie członkowie parlamentu' ${ }^{9}$. Założeniem angielskiej deklaracji było selektywne ograniczanie władzy suwerena, a nie uposażenie człowieka w uprawnienia ${ }^{10}$. Oprócz braku aspektu uniwersalności i równości, uprawnienia w Deklaracji Praw z 1689 r. nie są także ani przyrodzone, ani niezbywalne. Przeto cztery omawiane podstawy praw człowieka pierwszy raz pojawiają się w dokumencie z Wirginii.

III. George Mason urodził się na rodzinnej plantacji w hrabstwie Fairfax, w Wirginii. Dla osiemnastowiecznych kolonii angielskich w Ameryce Północnej, w odróżnieniu do ich metropolii, charakterystyczne było zróżnicowanie wyznań religijnych. Wirginia, najstarsza stała angielska kolonia w Nowym Świecie, odbiegała od owej reguły. Większość społeczeństwa należała do Kościoła anglikańskiego ${ }^{11}$. Dlatego też Kościół anglikański zyskał wśród osiemnastowiecznych mieszkańców Wirginii miano „Church of Virginia” ${ }^{2}$. Tak samo jak w metropolii, człowiek w chwili swoich narodzin na terytorium Wir-

5 Ibidem, s. 204.

6, ,...) good people of Virginia (...)”. Z. Kędzia, Prawa i Obowiązki..., s. 27.

$7,(\ldots)$ the basis and foundation of Government (...)". Ibidem.

${ }^{8}$ E. Randolph, Essay on the Revolutionary History of Virginia. Fragment eseju dotyczący Deklaracji Praw Wirginii znajduje się [w:] The Roots of The Bill of Rights..., s. 249.

9 „I rzeczeni powyżej Lordowie duchowni i świeccy oraz Gminy zebrawszy się (...) w pierwszym rzędzie dla (...) potwierdzenia i upomnienia się o swoje stare prawa i wolności (...)”. Przytoczony fragment Deklaracji Praw z 1689 r., tłum. przez Stanisława Gebethnera, znajduje się [w:] Z. Kędzia, Prawa i Obowiązki..., s. 25 n.

${ }^{10}$ L. Kühnhardt, Die Universalität der Menschenrechte, Bundeszentrale für politische Bidung, Bonn 1987, s. 69; Z. Ogonowski, Locke, Warszawa 1972, s. 40; A. Ryan, The British, the Americans, and rights, s. 366-439, [w:] A culture of rights. The Bill of Rights in philosophy, politics, and law 1791-1991, wyd. M. J. Lacey, K. Haakonssen, Cambridge 1992, s. 384.

11 T. E. Buckley, Patrick Henry, Religious Liberty, and the Search for Civic Virtue, s. 125-144, [w:] The Forgotten Founders on Religion and Public Life, wyd. D. Dreisbach, M. Hall, J. Morrison, Notre Dame 2009, s. 126.

12 David L. Holmes, The Faith of the Founding Fathers, Oxford i dalsze 2006, s. 33; Church of Virginia wywodzi się od Church of England, oficjalnego określenia Kościoła anglikańskiego w Anglii. 
ginii stawał się nie tylko obywatelem Anglii, lecz także członkiem Kościoła anglikańskiego ${ }^{13}$, z którym to ród Masonów utrzymywał bliskie stosunki ${ }^{14}$.

Po przedwczesnej śmierci ojca w $1735 \mathrm{r}^{15}$, opiekunem prawnym dziewięcioletniego George'a został jego wuj, adwokat John Mercer of Marlborough (1704-1768). Edukację religijną chłopiec otrzymał od swojej matki Ann Thomson (1699-1762) ${ }^{16}$ oraz od duchownego Alexandra Scotta (1686-1738), który wybierał dla niego książki, nieraz zamawiając je prosto z Anglii ${ }^{17}$. Prywatna biblioteka Masona w jego posiadłości Gunston Hall zawierała pozycję Book of Common Prayer ${ }^{18}$. Była to nie tylko książka liturgiczna, lecz także symbol anglikanizmu, m.in. w czasie naznaczonej konfliktami religijnymi angielskiej wojny domowej. W 1749 r. roku Mason został wybrany churchwarden'em swojej parafii. Od tego czasu na przemian sprawował dwa najważniejsze laickie urzędy parafialne ${ }^{19}$. Do obowiązków churchwardena należała zarówno odpowiedzialność za życie parafian i parafii w zgodzie z zaleceniami i nakazami Book of Common Prayer ${ }^{20}$, jak i nadzorowanie budowy nowych budynków kościelnych oraz troska o utrzymywanie już istniejących w odpowiednim stanie ${ }^{21}$. W imię miłości bliźniego churchwarden wspierał najsłabszych w społeczeństwie, biednych i niepełnosprawnych. Czynił to bezpośrednio poprzez wsparcie finansowe, pochodzące z podatków ściąganych przez parafie ${ }^{22}$, pośrednio zaś poprzez płacenie osobom godzącym się na przyjęcie potrzebującego na stałe do swego domu ${ }^{23}$.

13 Ibidem, s. 34.

14 W 1648 r. pierwsi pionierzy zaczęli osiedlać się na zachodnim brzegu Potomaku. Niespełna cztery lata później dołączył do nich przodek i zarazem imiennik Georga Masona przybywający z Pershore, z Anglii. Tradycja rodzinna utrzymuje, że jako pułkownik w obozie króla Karola I znalazł się po zwycięstwie Olivera Cromwella w angielskiej wojnie domowej po stronie pokonanych. Być może był to jeden z czynników, które wpłynęły na jego decyzje opuszczenia Anglii. Tym bardziej, że rządy zagorzałego purytanina Cromwella nie sprzyjały rojalistom wyznania anglikańskiego. W tzw. parlamencie kadłubowym nie było już dla nich miejsca. Dziadek Masona przewodził ruchowi Protestant Freemen, grupie lojalnych rojalistów, zwolenników króla Wilhelma III Orańskiego i królowej Marii z Modeny, którzy zobowiązali się bronić protestanckiej Wirginii przeciwko katolickim Jakobitom z kolonii Maryland. P. Copeland, R. MacMaster, The Five George Masons, Charlottesvilles 1975, s. 1, 9; H. Hill Miller, George Mason Constitutionalist, P. Smith, Gloucester 1966, s. 3.

15 George Mason III utonął 05 marca 1735 r. w rzece Potomak. P. Copeland, R. MacMaster, op. cit., s. 73 .

16 R.C. Mason, George Mason of Virginia, Citizen, Statesman, Philosopher, O.A. Morgner, New York 1919, s. 8 n.

17 P. Copeland, R. MacMaster, op. cit., s. 78.

18 J. Broadwater, George Mason Forgotten Founder, University of North Carolina 2006, s. 19.

19 Są to urzędy churchwarden oraz vestryman. P. Copeland, R. MacMaster, op. cit., s. 170.

20 Ibidem.

21 Ibidem, s. 171.

22 Ibidem, s. 173.

23 Ibidem. 
Dogłębna analiza życia duchowego George'a Masona nie jest łatwym zadaniem. Większa część jego rękopisów zaginęła ${ }^{24}$. Za co, po części, on sam ponosi odpowiedzialność. Mason, w przeciwieństwie do większości Ojców Założycieli, nie zabiegał o swój wizerunek wśród potomnych. Thomas Jefferson (1743-1826), James Madison (1751-1836) czy też John Adams (1735-1826) starannie zachowywali dokumentację swojej publicznej posługi dla przyszłych generacji ${ }^{25}$.

Skromna spuścizna po Masonie nie zawiera jednoznacznych wypowiedzi na temat jego stosunku do chrześcijaństwa. Zachowane dokumenty pozwalają jednak naszkicować jego nastawienie do Boga, do wiary. Przytoczone poniżej fragmenty nawiązujące do Boga są typowe dla zachowanej korespondencji George'a Masona: „Jedynie Bóg zna przebieg wydarzeń, i w Jego ręce, ufając w sprawiedliwość naszej sprawy, pogodnie ją zawierzamy!"26 (George Mason do Richarda Henry'iego Lee 1732-1794, dnia 1 czerwca 1775 r.). „Bóg był łaskawy pobłogosławić nasze dążenia w sprawiedliwej sprawie nadzwyczajnym sukcesem"27 (George Mason do pułkownika Georga Mercera 1733-1784, dnia 2 października 1778 r.).

Obie wypowiedzi odnoszą się do wspólnego dążenia do niepodległości, które Mason nazywa „naszą sprawą”. Pierwsza wypowiedź powstała zaledwie pięć tygodni od bitwy pod Lexington i Concord ${ }^{28}$. „Nasza sprawa” zostaje złożona w ręce Boga. Tylko Bóg zna jej rozstrzygnięcie. Wprawdzie ani kontekst wypowiedzi, ani nadmieniona niefortunna sytuacja dotycząca spuścizny po Masonie nie pozwalają na ostateczny osąd w kwestii ustalenia istoty Boga w ujęciu Masona. Można jednak stwierdzić, że jest to Bóg znający bieg historii oraz godny nadziei w Nim pokładanej. Nie jest to nieosiągalny Bóg deistów, który wycofał się po stworzeniu wszechświata. Jeszcze wyraźniej owa dystynkcja wyłania się w drugim cytacie. Mason czyni Boga odpowiedzialnym za dotychczas osiągnięte nadzwyczajne sukcesy. Jest to Bóg ingerujący w bieg wydarzeń, decydujący o tym, którą stronę konfliktu pobłogosławić i doprowadzić do zwycięstwa.

24 maja 1774 r. zgromadzenie przedstawicieli Wirginii, „the House of Burgesses", uchwaliło dzień 1 czerwca dniem modlitwy i postu ${ }^{29}$. Celem

24 D.L. Dreisbach, Famous Founders and Forgotten Foudners. What's the Difference, and Does the Difference Matter?, s. 1-25, [w:] The Forgotten Founders..., s. 12.

25 Ibidem, s. 7, 13.

26 ,God only knows the event, and in His hands confiding in the justice of our cause, we cheerfully trust it!". K. Mason Rowland, The Life of George Mason, 1725-1792, Volume I, New York 1892, s. 194.

27 "God has been pleased to bless our endeavors in a just cause with remarkable success". K. Mason Rowland, op. cit, s. 300.

28 Jako początek rewolucji przyjmuje się potyczkę pod Lexington i Concord z dnia 14 kwietnia $1775 \mathrm{r}$.

29 J. Broadwater, op. cit., s. 64. 
uchwały było ubłaganie boskości ${ }^{30}$ o zaniechanie niebezpieczeństw ${ }^{31}$ wynikających z uchwalenia przez parlament brytyjski ustaw, określanych jako „Intolerable Acts"32. Stanowiły one odpowiedź rządu brytyjskiego na ,herbatkę bostońską"33. Mason, przebywający wówczas prywatnie w Williamsburgu, napisał w liście do Martina Cockburna ${ }^{34}$. „Winien dzień modlitwy i postu zostać w naszym kraju wyznaczony, proszę przekazać mojej kochanej małej rodzinie, iż wymagam od nich jego uszanowania, i że pragnę by moi trzej najstarsi synowie oraz moje dwie najstarsze córki mogły w żałobie uczestniczyć w nabożeństwie, jeżeli będą do tego zobowiązane, a wierzę, że będą" 35 .

Treść zdania nie brzmi jak nakaz do spełnienia cywilnego obowiązku. Wręcz przeciwnie, opis nastawienia, w jakim dzieci Masona mają udać się do kościoła, wskazuje, iż Mason kładł nacisk na religijny element uszanowania dnia modlitwy i postu. Jako jeden z czterech proponowanych przez D. Holmesa wskaźników, mających pomóc odróżnić chrześcijanina od deisty w okresie powstawania Stanów Zjednoczonych Ameryki, jest uczestnictwo we mszy świętej ${ }^{36}$. Biograf Masona, R. C. Mason, stwierdził, iż George Mason ,żył i zmarł jako szczery chrześcijanin"37. Niemożliwe jest wsparcie tejże wypowiedzi wystarczającymi argumentami. Z drugiej strony nie istnieją ślady, które by ją mogły podważyć. Spadek po Masonie nie zawiera fragmentów wskazujących na deistyczny charakter jego wiary. Podsumowując, rysuje się obraz człowieka, przynajmniej na zewnątrz, do końca życia oddanego Kościołowi anglikańskiemu.

IV. Idee i koncepcje Johna Locke’a wywarły duży wpływ na Ojców Założycieli. Mason nie był wyjątkiem. Wręcz przeciwnie, w swoich publikacjach

30 Posłużono się neutralnym, niepodporządkowanym konkretnej wierze pojęciem divinity.

31 Do niebezpieczeństw należała grożba wojny domowej i ograniczenie praw obywatelskich.

32 J. Broadwater, op. cit., s. 64

33 Herbatką bostońską określa się wrzucenie ładunków herbaty z trzech statków do morza przez grupę przebranych za Indian Bostończyków w Boston Harbour 16 grudnia 1773 r., jako znak protestu przeciwko Tea Act, ustawie uchwalonej przez brytyjski parlament. Tea Act wprawdzie obniżył cenę herbaty, lecz nie zniósł jej opodatkowania. Podatek na herbatę został uchwalony 7 lat wcześniej, stanowiąc kolejne naruszenie jednego z głównych przekonań kolonistów - ,no taxation without representation". Koloniści uważali, iż brytyjski parlament nie ma prawa nakładania podatków na kolonie, dopóki nie zasiądą w nim ich reprezentanci.

34 Pisząc swój testament w 1773 r., Georgie Mason mianował swojego przyjaciela i sąsiada Martina Cockburna (1742 - data śmierci nieznana) opiekunem prawnym swoich dzieci. P. Copeland, R. MacMaster, op. cit, s. 89.

35 ,Should a day of Prayer and fasting be appointed in our country, please to tell my dear little Family that I charge them to pay strict Attention to it, and that I Desire my three eldest sons, and my two eldest daughters, may attend church In Mourning, if they have it, as I believe they have". P. Copeland, R. MacMaster, op. cit. s. 183.

${ }^{36}$ Inne wskaźniki to nastawienie do sakramentów i obrządków, poziom aktywności oraz język religijny. D.L. Holmes, op. cit., s. 140.

$37,(\ldots)$ he lived and died a sincere Christian (...)”. R.C. Mason, op. cit., s. 13. 
szeroko przytaczał locke'owskie koncepcje. Locke nie był jedynym źródłem inspiracji dla wprowadzającego artykułu Deklaracji Praw Wirginii, ale bez wątpienia najważniejszym ${ }^{38}$.

Ze spuścizną ideową brytyjskiego myśliciela Mason zapoznawał się, będąc pod opieką swojego wuja, Johna Mercera, w jego znamienitej bibliote$\mathrm{ce}^{39}$. Sam był w posiadaniu egzemplarza Dwóch traktatów o rządzie ${ }^{40}$.

Dwa traktaty... zawierają właściwie wszystkie idee pierwszej części pierwszego artykułu Deklaracji Praw Wirginii. Koncepcję wszystkich ludzi $\mathrm{z}$ natury równo wolnych i niezależnych odnaleźć można $\mathrm{w}$ pierwszym traktacie jako część polemiki z Robertem Filmerem (1588-1653), reprezentującym przeciwne stanowisko, nieuznającym naturalnej wolności człowieka ${ }^{41}$. M.in. na idei z natury równo wolnych i niezależnych ludzi budowane są konstrukcje drugiego traktatu. Zgodnie z jego zapisem człowiek, dobrowolnie przystępujący do społeczeństwa, nie zrzeka się wszystkich uprawnień przyrodzonych, którymi był obdarzony w stanie natury. Nie jest w stanie się ich zrzec, ponieważ nie podlegają one jego władzy.

W celu dogłębniejszego zrozumienia treści wprowadzającego artykułu Deklaracji Praw Wirginii sięgnięcie jedynie do dzieła Dwa traktaty... nie wystarcza. Konieczne jest posłużenie się całą spuścizną po Locke'u.

Rozważania rozpocząć należy od uniwersalności jako podstawy praw człowieka. Konieczne jest udzielenie odpowiedzi na pytanie, czy rozpoczynające art. 1 „wszyscy ludzie” rzeczywiście obejmuje każdego człowieka?

Kluczem do odpowiedzi jest locke'owska koncepcja człowieka. Locke pojmuje go przede wszystkim poprzez jego relacje z Bogiem. Ludzie są dziełem Boga i Jego własnością ${ }^{42}$. Z tejże relacji wywodzi się obowiązek zachowania siebie i innych ludzi przy życiu oraz obowiązek posłuszeństwa swemu Stwórcy ${ }^{43}$.

Inne niż ludzie istoty również są Jego stworzeniami. Jak więc odróżnić człowieka od innych żywych istot? Według Locke'a decydującą rolę odgrywa rozum, expressis verbis wymieniony przez autora Dwóch traktatów... jako

38 Tego zdania są także: O. Patterson, Freiheit, Sklaverei und die moderne Konstruktion der Rechte, s. 164-218, [w:] Die kulturellen Werte Europas, Frankfurt am Main 2006, s. 198; J. Hutson, The Bill of Rights and the American Revolutionary experience, s. 62-97, [w]: A Culture of Rights. The Bill of Rights in philosophy..., s. 78; J. M. Murrin, Can Liberals be Patriots? Natural Right, Virtue, and Moral Sense in the America of George Mason and Thomas Jefferson, s. 35-65, [w:] Natural Rights and Natural Law: The Legacy of George Mason, Fairfax 1986, s. 47; R.P. Davidow, Introduction, s. 1-31, [w:] Natural Rights and Natural Law: The Legacy..., s. 3.

39 H. Hill Miller, George Mason, Gentleman Revolutionary, University of North Carolina Press 1975, s. 159; P. Copeland, R. MacMaster, op. cit., s. 76 n.

40 J. Broadwater, op. cit., s. 9.

41 J. Locke, Dwa traktaty o rzadzie, thum. Z. Rau, Warszawa 1992, Traktat pierwszy, § 6 i $§ 28$.

42 J. Locke, Dwa traktaty..., Traktat drugi, § 6 .

43 Ibidem. 
właściwość nadana człowiekowi przez Boga ${ }^{44}$. Lecz rozum mają także i zwierzęta ${ }^{45}$, więc cechą odróżniającą nie może być jedynie możność rozumowania sama w sobie. W porównaniu do innych żywych istot, człowiek potrafi tworzyć idee ogólne ${ }^{46}$ poprzez odrywanie idei od poszczególnych rzeczy ${ }^{47}$. W tejże umiejętności abstrahowania Locke postrzega różnice między ludźmi a zwierzętami ${ }^{48}$. Czyżby owa idea wystarczała jako element pozwalający zakwalifikować żywą istotę jako człowieka? Nietrudno wszak napotkać osobę niewykazującą umiejętność abstrakcji ${ }^{49}$. Mogła stracić ją za życia, lub bez niej się narodzić50. Wiara pomaga Locke'owi wyjść z tej trudniej sytuacji. Dostrzega on bowiem, iż istnieje podstawowa cecha ludzkiej rozumności, która odróżnia gatunek ludzki od zwierząt i zarazem nie wymaga umiejętności abstrakcji. Każdy człowiek, także niepotrafiący abstrahować, ma na tyle „Światła rozumu”, by móc dotrzeć do wiedzy o swoim Stworzycielu ${ }^{51}$, czy to za pomocą objawienia, czy też drogą wiary.

Jest to konstrukcja, którą można odnaleźć już we wczesnym, niepublikowanym za życia dziele Locke'a, Questions concerning the Law of Nature ${ }^{52}$. Od sformułowania, które znalazło się w Rozważaniach dotyczacych rozumu ludzkiego, różni się ono jedynie perspektywą wypowiedzi. W Questions... człowiek obdarzony przez naturę możnością poznania Boga dociera do wiedzy o Nim, jeżeli tylko nie zaniecha skorzystania ze swych kognitywnych umiejętności ${ }^{53}$.

Istnieją więc dwie drogi prowadzące do poznania Boga, poznania konstytuującego człowieka. Pierwszą jest droga abstrakcyjnego rozumowania, drugą drogą jest poznanie Boga poprzez objawienie i wiarę. Czy można z tego wyciągnąć wniosek, że chrześcijanie są uprzywilejowani w wykorzystywaniu rozumu do poznania Boga i przez to łatwiej im dotrzeć do pełnego człowieczeństwa? Czy są w korzystniejszej sytuacji, dlatego iż otrzymali możliwość usłyszenia dobrej nowiny? Gdyby tak było, pozostałby niesmak niesprawiedliwości. Ileż jest ludzi na świecie, którzy nie mieli i nie mają dostępu do wiary chrześcijańskiej. Problem ten Locke podejmuje przy końcu swego życia

44 Ibidem, $\S 11$.

45 J. Locke, Rozważania dotyczace rozumu ludzkiego, Księga II, Rozdział 11, § 11.

46 Ibidem, $\S 10$.

47 Ibidem, $\$ 9$.

48 Ibidem, $\S 10$.

49 Ibidem, $\S 12$.

50 Ibidem.

51 Ibidem, Księga I, Rozdział 1, § 5.

52 Locke nie nadał tytułu swoim ośmiu, napisanym w języku łacińskim, pytaniom dotyczącym prawa natury. W 1954 r. Wolfgang von Leyden, edytując i tłumacząc pytania, tytułował je $E s$ says on the Law of Nature. Niniejszym cytowane jest nowsze thumaczenie pytań z 1990 r., którym Robert Horwitz nadał, według swej opinii, bardziej trafny tytuł: Questions concerning the Law of Nature.

53 J. Locke, Questions concerning the Law of Nature, New York 1990, s. 165. 
w dziele Reasonableness of Christianity, as delivered in the Scriptures. Pisze w nim o Bogu, który zaszczepia każdemu człowiekowi „światło rozumu”, niezależnie od przynależności do chrześcijańskiej religii, czy jej znajomości ${ }^{54}$. Obowiązek dotarcia do Boga należy i tutaj do człowieka obdarzonego wolną wolą przy podejmowaniu decyzji odnośnie do tego czy i jak skorzysta z, jak pisze Locke, „Świecy Pana" ${ }^{55}$. W tej kwestii wyłania się koherentny obraz schematu konsekwentnie używanego przez Locke'a, nieraz słusznie krytykowanego za antynomie w swojej myśli. Jego pogląd na temat jakże ważnego potencjału poznawalności Boga w Questions... z 1664 r. nie różni się od wersji głoszonej w Reasonableness... z 1695 r. Schemat Boga dostępnego wszystkim ludziom w równy sposób jest według Locke’a zgodny z nauczaniem Jezusa. „Ale nasz Zbawiciel, kiedy przyszedł, obalił tą ścianę podziałów; I nie ograniczał swych cudów i swego przesłania do ziemi Kanaan, czy też do wyznawców w Jerozolimie (...) A po Zmartwychwstaniu, wysłał swoich apostołów wśród narody (...)"56. Locke przytacza Jezusa jako nauczyciela każdego człowieka, niezależnie od wyznania. Pojęcie „wszyscy ludzie” obejmuje wszystkie istoty spełniające locke’owskie warunki bycia człowiekiem. Podsumowując, warunek ten jest spełniony przez każdą żywą istotę potencjalnie obdarzoną ,światłem rozumu” w wystarczającej ilości, by móc w ten czy inny sposób dotrzeć do Boga. Każdy człowiek spełnia warunek postawiony przez Locke’a, przeto termin ,wszyscy ludzie” we wprowadzającym artykule Deklaracji Praw Wirginii, przynajmniej w teorii, obejmuje każdego człowieka. W teorii, gdyż nie można pominąć problematyki niewolnictwa. W czasie pierwszego cenzusu przeprowadzonego w Stanach Zjednoczonych w $1790 \mathrm{r}$. z 3,9 miliona mieszkańców 697 tysięcy żyło w niewoli ${ }^{57}$. Szczególnie wysokie zapotrzebowanie na niewolników ze względów gospodarczych istniało w południowych koloniach. Trzy lata przed ogłoszeniem Deklaracji Praw Wirginii niewolnicy stanowili aż połowę z 500 tysięcy mieszkańców Wirginiii ${ }^{58}$. Ich sytuacja nie poprawiła się po ogłoszeniu Deklaracji, której locke’owska treść definicji człowieka jednoznacznie nie dokonywała podziału na podstawie koloru skóry, tylko na podstawie intelektualnej możności poznania Boga.

Antynomia pomiędzy brzmieniem pierwszego artykułu Deklaracji Praw Wirginii, jego locke’owską treścią a instytucją niewolnictwa, jest z dzisiejsze-

54 J. Locke, The Reasonableness of Christianity, as delivered in the Scriptures, s. 85-210, [w:] John Locke, Writings on Religion, Oxford 2002, s. 190.

55 „Candle of the Lord”, ibidem.

56 „But our Saviour, when he came, threw this Wall of Partition; And did not confine his Miracles or Message to the Land of Canaan, or the Worshippers at Jerusalem (...) And after his Resurrection, sent his Apostles among the Nations...". J. Locke, The Reasonableness..., s. 194.

57 F. McDonald, Novus Ordo Seclorum, The Intellectual Origins of the Constitution, Lawrence 1985 , s. 50.

${ }^{58}$ H. Mayer, A Son of Thunder, Patrick Henry and The American Republic, New York 1986, s. 167. 
go punktu widzenia niewątpliwa. Podobnie jak sprzeczność pomiędzy potępianiem niewolnictwa w teorii przez wielu Ojców Założycieli, a posiadaniem przez nich niewolników. Na plantacji tytoniu Masona pracowali niewolnicy będący jego własnością ${ }^{59}$. W tej kwestii nie różnił się od innych właścicieli ziemskich z Wirginii, w tym od Thomasa Jeffersona i George'a Washingtona (1732-1799).

Równocześnie Mason krytykował instytucję niewolnictwa na konwencji w Williamsburgu w 1776 r. i na konwencji w 1787 r. poprzedzającej uchwalenie konstytucji Stanów Zjednoczonych. Na tej ostatniej oznajmił, iż „każdy właściciel niewolników rodzi się małym tyranem"60. Jeszcze przed wojną o niepodległość angażował się w zatrzymanie dalszego importu niewolników do Wirginii. W 1769 r. wraz z Richardem Henry'm Lee załączył do dokumentu o nazwie Virginia Association, ograniczajacego import do kolonii, punkt o treści: „(...) nie importować żadnego niewolnika oraz nie kupować importowanego(...)"'61.

Każdy przedstawiciel gatunku ludzkiego jest z ,natury równo wolny i niezależny". Sam tekst Deklaracji nie odpowiada na pytanie, kim lub względnie czym jest natura odpowiedzialna za równe uprawnienie każdego człowieka do wolności i niezależności. Pomocne okazać się może przyjrzenie się wcześniejszym wersjom pierwszego półzdania omawianego artykułu. Pierwszy raz sformułowanie to pojawia się u Masona w Remarks on Annual Elections for the Fairfax Independent Company ${ }^{62} \mathrm{z}$ kwietnia 1775 r.: „Wszyscy ludzie rodzą się z natury równo wolni i niezależni (...)"63.

W swoim szkicu z dni poprzedzających 26 maja 1776 r. na konwencji w Williamsburgu Mason, jako członek komitetu redakcyjnego, zmienił nieco wersje z Remarks ... na: ,(...) wszyscy ludzie są stworzeni równo wolni i niezależni (...)"'64.

W dniu 27 maja 1776 r. Archibald Cary (1721-1787) jako przedstawiciel komitetu redakcyjnego odczytał na posiedzeniu konwencji szkic przygotowany przez komitet: „(...) wszyscy ludzie rodzą się równo wolni i niezależni $(\ldots)^{\prime \prime 65}$.

Pisząc historię Wirginii, trzydzieści lat po historycznych wydarzeniach w Williamsburgu, członek komitetu redakcyjnego, Edmund Randolph, stwierdził, iż szkic Deklaracji Praw Wirginii autorstwa George’a Masona ,ppołk-

59 P. Copeland, R. MacMaster, op. cit., s. 162.

60 „Every master of slaves is born a petty tyrant”. F. McDonald, op. cit., s. 50.

61 „,not to import any slave, or buy an imported”. P. Copeland, R. MacMaster, op. cit., s. 165.

62 „Remarks...” uzasadniały utworzenie niezależnej milicji dla hrabstwa Fairfax.

63 „All men are by nature born equally free and independent... " The Papers of George Mason, 1725-1792, Volume 1, University of North Carolina Press 1970, s. 229.

$64,(. .$.$) all men are created equally free and independent (...)”. The Roots of The Bill of$ Rights..., s. 242.

$65,(\ldots)$ all men are born equally free and independent (...)”. Ibidem, s. 237. 
nął" ${ }^{66}$ wszystkie inne propozycje. Porównanie szkicu Masona z 26 maja ze szkicem odczytanym przez Archibalda Cary'ego dzień później oraz z wersją ostateczną potwierdza tezę, iż wzorowano się na szkicu Masona. Pojęcia „rodzą się z natury”, „są stworzeni”, „rodzą się” czy „,z natury” wydają się być zamienne i przekazywać tę samą treść. W celu weryfikacji twierdzenia należy przyjrzeć się, jak terminy te używał autor, od którego Mason i komitet redakcyjny je przejęli. Użycie wyrazu ,stworzeni” w jednym z wariantów wskazuje, iż za wymiennymi sformułowaniami może kryć się treść - „Bóg stworzył człowieka”. Bóg w roli Stworzyciela człowieka występuje wielokrotnie u Locke'a ${ }^{67}$. Locke nie tylko przejmuje teorię stworzenia człowieka przez Boga, lecz konstruuje dowód mający dowieść jej prawdziwości. Człowiek nie może, podobnie jak Bóg, być sam sobie przyczyną, dlatego że w swej niedoskonałości odbiega tak bardzo od człowieka, jakiego może sobie wyobrazić rozum $^{68}$. Gdyby człowiek był stworzycielem samego siebie, stworzyłby siebie najlepiej jakby potrafił ${ }^{69}$. Byłoby to koniecznością, gdyż niewyobrażalna jest istota mogąca być tak wrogo nastawiona wobec siebie, by nie obdarzyła siebie samej nieśmiertelnością ${ }^{70}$. W Questions... Locke pisze, że rozum jest nadany $\mathrm{z}$ natury ${ }^{71}$. Podczas rozumowania nad istotą człowieka przytoczony został cytat z Dwóch traktatów..., oznajmujący, iż dawcą rozumu jest Bóg ${ }^{72}$. Nie jest to jedyny przykład zamiennego stosowania pojęć „natura” i „Bóg” w dziełach Locke'a. W Rozważaniach... czytamy, że Bóg uposaża człowieka w umiejętność Jego poznania ${ }^{73}$. Opisując tą samą umiejętność w Questions... jako jej źródło Locke przytacza naturę ${ }^{74}$. Odmienna interpretacja pojęcia „,z natury” jest niedostrzegalna. „Z natury” w pierwszym artykule Deklaracji znaczy więc stworzeni przez Boga. Stworzeni przez Boga „równo wolni i niezależni”.

Jak i dlaczego Bóg stworzył ludzi równo wolnych i niezależnych, i co atrybuty te oznaczają? Człowiek został stworzony przez Boga na jego obraz i podobieństwo, dlatego że Bóg tego chciał. Jako Jego własność człowiek jest zdany na Jego wolę. Bóg decyduje o przyjściu na świat istoty ludzkiej, o jej zachowaniu przy życiu, czy też o momencie śmierci ${ }^{75}$. Wobec Boga panuje między ludźmi bezwzględna równość. W Liście o tolerancji Locke pisze, iż

66 „George Mason swallowed up all the rest, by fixing the grounds and plan, which after great discussion and correction, were finally ratified". E. Randolph, op. cit., s. 247.

67 J. Locke, Questions..., s. 229; idem, Dwa traktaty..., Traktat drugi, § 56; idem,, Dwa traktaty..., Traktat pierwszy, $\S 26$.

68 Idem, Questions..., s. $161 \mathrm{n}$.

69 Ibidem.

70 Ibidem.

71 Ibidem, s. 109.

72 J. Locke, Dwa traktaty..., Traktat drugi, § 11.

73 J. Locke, Rozważania..., Księga I, Rozdział 1, § 5.

74 Idem, Questions..., s. 165.

75 Ibidem, s. 163. 
„Książęta rodzą się wprawdzie swą władzą wyżsi od innych, ale naturą równi reszcie śmiertelnych..."76. Każdy człowiek, nawet i książę, jest z natury równy każdemu innemu człowiekowi. Przypominając zamienność pojęć „,natura” i „Bóg”, można powiedzieć, że człowiek w akcie stworzenia na podobieństwo Boga równa się każdemu innemu człowiekowi. Z tej równości wywodzi się naturalna równość w wolności i niezależności.

Po stworzeniu przez Boga człowiek znajdował się w stanie natury, w którym ,(...) jeden człowiek jest równy drugiemu (...)"77. Jest to równość ,(...) wszystkich ludzi zarówno pod względem jurysdykcji, jak i panowania jednego nad drugim"78. Jest to równe uprawnienie każdego człowieka ,„...) do swej naturalnej wolności (...)"79, mające na celu niezależność od woli i władzy innych ludzi ${ }^{80}$. Niezależność i wolność są ściśle połączone z rozumem, gdyż jest on niezbędnym narzędziem w ich uświadamianiu ${ }^{81}$.

„Wszyscy ludzie są z natury nie tylko równo wolni i niezależni”, ale posiadają także i pewne niezbywalne przyrodzone prawa. Użycie terminu „,posiadają" na początku pierwszego artykułu Deklaracji Praw Człowieka wskazuje na stosunek własnościowy. Podmiotem posiadającym jest człowiek, obiektem posiadania są pewne niezbywalne uprawnienia. Owe uprawnienia rzeczywiście są objęte poprzez jedno z dwóch pojęć własności używanych przez Locke'a. Podlegają pod tzw. własność szeroko rozumianą ${ }^{82}$, obejmującą m.in. człowieka jako właściciela swojego życia. Własność wąsko rozumiana ogranicza się do majątku. N. Gładziuk zwraca uwagę na antynomię u Locke’a dotyczącą własności ${ }^{83}$. Z jednej strony człowiek jest własnością Boga, który go stworzył i przez to może i uśmiercić, z drugiej zaś strony można u Locke’a znaleźć wypowiedź, iż człowiek w stanie natury jest ,,(..) absolutnym panem własnej osoby i majątku, równy najpotężniejszym i nie podlega nikomu (...)"84. Jedna wypowiedź zdaje się wykluczać drugą, tym bardziej, że Locke posługując się terminem „,absolutny”, wyraźnie eliminuje związek współwłasnościowy Boga i człowieka. Po scharakteryzowaniu człowieka jako absolutnego pana własnej osoby, Locke zrównuje go z najpotężniejszymi. Używając liczby mnogiej, nie równa człowieka z Najpotężniejszym, czyli z Bogiem, tylko z przynajmniej kilkoma osobami posiadającymi władzę. Dopasowując całe zdanie do związku pojedynczego człowieka nie

76 J. Locke, List o tolerancji, thum. L. Joachimowicz, red. Z. Ogonowski, Warszawa 1963, s. 27.

77 J. Locke, Dwa traktaty..., Traktat drugi, § 123.

78 Ibidem, § 54 .

79 Ibidem.

80 Ibidem.

81 Ibidem, $\S 63$.

82 Ibidem, $§ 173$.

83 N. Gładziuk, Druga Babel, Antynomie siedemnastowiecznej angielskiej myśli politycznej, Warszawa 2005, s. 332, 342 n.

${ }^{84}$ J. Locke, Dwa traktaty..., Traktat drugi, § 123. 
z Bogiem, lecz z resztą ludzkości, pojęcie „absolutny” i zwrot „nie podlega nikomu" zachowują swoją ważność, nie tworząc tym samym sprzeczności, gdyż nie podważają własności Boga. Człowiek jest absolutnym, niepodlegającym żadnemu innemu człowiekowi panem swej osoby. Jego własność ograniczyć może tylko pozaziemski właściciel, czyli Bóg. Jako przykład ograniczenia może służyć zakaz uśmiercenia siebie samego. Człowiek nie ma prawa sam siebie unicestwić, nie może też bezprawnie, wyłączając wyjątkowe przypadki - gdy zagraża uprawnieniu samozachowania innego człowie$\mathrm{ka}^{85}$ - zostać przez niego unicestwiony. Tylko Bóg posiada prawo do odebrania życia i innych niezbywalnych uprawnień w każdej chwili, bez powodu, wedle własnej woli. Według art. 1 Deklaracji Praw Wirginii człowiek przystępujący do społeczeństwa nie zostaje pozbawiony wszystkich uprawnień, które posiada w stanie natury. Gdyby Mason urzeczywistniał myśl Thomasa Hobbes'a (1588-1679) ${ }^{86}$, czy też Jana Jakuba Rousseau (1712-1778), a nie Locke’a, byłby zmuszony w tekście Deklaracji pozbawić przystępującego do społeczeństwa wszelkich uprawnień.

Nasuwa się pytanie, dlaczego człowiek w ogóle przystępuje do społeczeństwa, jeżeli w stanie natury nie tylko jest ziemskim ,(...) panem własnej osoby i majątku (...)"87, ale jest także równo wolny i niezależny. Odpowiedź na nie jest połączona $z$ definicją stanu natury u Locke'a. Na początku traktatu drugiego Dwóch traktatów... rzeczywiście opisany jest stan natury niewarty opuszczenia, „stan zupełnej wolności”"88 i „równości” ${ }^{89}$. Czytając dalej, idylla panująca $\mathrm{w}$ stanie natury zamienia się w bardziej hobbes'owski obraz ${ }^{90}$. Człowiek „nieustannie narażony na napady innych" ${ }^{91}$ żyje w stanie „pełnym strachu i ciągłych niebezpieczeństw”" ${ }^{\prime 2}$. Właściwe są mu „złośliwość, namiętności i chęć zemsty" ${ }^{93}$. L. Strauss przyjmuje różnice w przedstawieniu „stanu, w jakim ludzie znajdują się naturalnie"94 jako próbę zakamuflowania niepopularnej wtenczas hobbes'owskiej wizji stanu natury, z którą Locke miał jakoby potajemnie sympatyzować ${ }^{95}$.

85 Ibidem, $\S 8$.

86 Pojęciem stanu natury, w nowożytnym ujęciu stanu poprzedzającego przystąpienie człowieka do społeczeństwa poprzez zawarcie umowy społecznej, posługiwał się już autor Lewiatana, angielski filozof Thomas Hobbes. Zrzeknięcie się wszelkich uprawnień przez człowieka przystępującego do społeczeństwa u Hobbes’a i później u Rousseau odróżniało przebieg przystępowania do społeczeństwa od locke'owskiego zachowania pewnych przyrodzonych uprawnień.

87 J. Locke, Dwa traktaty..., Traktat drugi, § 123.

88 Ibidem, $\S 4$.

89 Ibidem.

90 Ibidem, § 123.

91 Ibidem.

92 Ibidem.

93 Ibidem, $\S 13$.

94 Ibidem, § 4.

95 L. Strauss, Prawo Naturalne w Świetle Historii, tłum. T. Górski, Warszawa 1969, s. 203 nn. 
Inna opinia, w Polsce przejęta przez Z. Raua, głosi, iż Locke miał na myśli dwa różne stany natury. $W$ tzw. właściwym stanie natury człowiek w pierwszym rzędzie dąży do przestrzegania prawa natury i w odróżnieniu do zwykłego stanu natury, odnosi w swym dążeniu pomyślny rezultat ${ }^{96}$. Zwykły stan natury jest zaś nie tylko historyczną rzeczywistością, ale i stanem mającym miejsce wszędzie tam, gdzie nie ma społeczeństwa obywatelskiego.

Teoria dwóch różnych stanów natury wydaję się bardziej przekonująca. Gdyby Locke rzeczywiście zamierzał nie być kojarzony z Hobbes'em, ukryłby umiejętniej swoje prawdziwe wyobrażenie o stanie natury. Oszczędziłby sobie trudu dementowania oskarżeń o powielanie myśli publicznie potępianego Hobbes'a. Teoria dwóch różnych stanów natury może zostać poddana próbie wytłumaczenia na tle myśli Locke'a. Był on oskarżany o sympatyzowanie z socynianizmem, nurtem religijnym wywodzącym się od Fausta Socyna (1539-1604), którego teologię cechuje bezgraniczny prymat rozumu. Objawienie według socynian tylko wtedy zachowuje swoją ważność, jeśli jest zgodne z logiką rozumu. Dogmat Trójcy Świętej, grzechu pierworodnego, czy też preegzystencja Jezusa nie są do pogodzenia z logicznym rozumowaniem i są dogmatami błędnymi. Oskarżenie opierało się m.in. o domyślne zaprzeczenie egzystencji grzechu pierworodnego. Stosunek Locke'a do tego zagadnienia z pewnością nie był ortodoksyjny. Próbował on złagodzić teorię przechodzenia wiecznego potępienia wszystkich ludzi z pokolenia na pokolenie, poczynając od Adama i Ewy ${ }^{97}$. Nie negował jednak bynajmniej upadku człowieka w następstwie grzechu pierworodnego. Upadek uwidaczniał się w ludzkiej śmiertelności i w skazaniu na moralną niedoskonałość ${ }^{98}$. Po upadku człowieka właściwy stan natury nigdy więcej nie może stać się w pełni rzeczywisty, pozostaje ,aprioryczną hipotezą" ${ }^{99}$. Hipotezą, w której nie ma „różnicy między tym jak ludzie winni się zachowywać, a tym, jak się zachowują" 100 .

Człowiek po upadku nie jest już w stanie żyć w stanie doskonałej symbiozy z prawami natury. Uniemożliwia to niedostateczność jego moralnej kondycji. Ale nie traci przez to na znaczeniu ważność właściwego stanu natury. Jego rola jako punktu odniesienia dla ludzi żyjących, czy to w zwykłym stanie natury, czy w społeczeństwie, jest niepodważalna. Mając na uwadze tkwienie ludzi w zwykłym stanie natury, dobrowolne zrzeknięcie się części uprawnień jest zrozumiałe, zważywszy na panujące niedogodności.

${ }^{96}$ Z. Rau, Umowa spoleczna w doktrynie Johna Locke'a, s. 127-151, [w:] Umowa spoleczna i jej krytycy w myśli politycznej i prawnej, red. Z. Rau, M. Chmielinski, Warszawa 2010, s. 133 nn.

97 J. Locke, The Reasonableness ..., s. 92 nn.; J. Locke, Peccatum originale i Homo ante et post lapsum, s. 229-231, [w:] idem, Writings on Religion..., s. $229 \mathrm{nn}$.

98 Ibidem.

99 Z. Rau, op. cit., s. 134.

${ }^{100}$ Ibidem, s. 133. 
Zaprzeczenie preegzystencji Chrystusa, egzystencji przed zrodzeniem z dziewicy Marii, było kolejnym argumentem na rzecz zbliżenia Locke'a do teologii socynian. Do głównych oskarżycieli należał duchowny John Edwards (1637-1716). W niespełna kilka miesięcy po ukazaniu się Reasonableness... Edwards napisał Some Thoughts Concerning The Several Causes and Occasions of Atheism, a rok później książkę o znamiennym tytule Socynianism Unmask'd. Locke nie pozostał jednak jego dłużnikiem i w odpowiedzi, przede wszystkim na zarzuty ze strony Edwardsa, powstały dwie próby swego rodzaju „windykacji” Racjonalności Chrześcijaństwa. W pierwszej windykacji Locke już na samym początku nawiązuje do Edwardsa i w ironiczny, znany z polemiki z Filmerem, sposób próbuje ośmieszyć jego wywody ${ }^{101}$. Także w pierwszej windykacji Locke jednoznacznie stwierdza: „Powtarzam ponownie, nie ma w niej [w Reasonableness of Christianity] ani słowa socynianizmu"102. Nieprawność zarzutu negowania preegzystencji Chrystusa potwierdza np. fragment z notatnika o tytule Adversaria Theologica 94, należącego do prywatnej biblioteki Locke'a. Pod podtytułem Christus non merus homo znajduje się zdanie: „Dlatego że jego Duch był w starożytnych prorokach i Pet. I. 11 JL"103. Scharakteryzowanie ponadludzkości Jezusa należy do najbardziej zawiłych kwestii teologicznych przemyśleń Locke’a. Jej rzetelne omówienie wykracza poza granice niniejszego artykułu. Konsekwencją wypowiedzi jest potwierdzenie ponadludzkości Jezusa. Dla odparcia zarzutu socynianizmu nie jest ono jednak konieczne, gdyż obecność Jezusa „W prorokach" Starego Testamentu oznacza jego egzystencję przed wydarzeniem w Betlejem i tym samym przeciwstawia się jednemu z głównych przekonań socynianizmu.

Obok oskarżenia o socynianizm, zarzucano Locke'owi także przynależność do grona deistów. By jej zaprzeczyć, nie trzeba zagłębiać się w interpretacje jego tekstów. Wystarczy przytoczyć chociażby jedno z wielu miejsc, w których Locke aprobuje niezbędność, zbędnego dla deisty ${ }^{104}$, objawienia, szczególnie w postaci zmartwychwstania Jezusa. W Reasonableness... zmartwychwstanie Jezusa nie ulega wątpliwości. Obok życia i śmierci Jezusa jest ono „bezspornym dowodem, iż był on Mesjaszem” ${ }^{105}$. Dlaczego kojarzono Locke'a z deistami, mimo wypowiedzi wyraźnie przeczących ich fundamentalnym przekonaniom? W. Spellman przytacza wytłumaczenie przekonujące

101 J. Locke, A Vindication of the Reasonableness of Christianity, s. 211-225, [w:] idem, Writings on Religion..., s. $214 \mathrm{nn}$.

102 „For I repeat it again, there is not one word of Socinianism in it”. Ibidem, s. 215.

103 „Because his spirit was in the ancient prophets i Pet. I. 11 JL”. Zdanie nawiązuje do myśli zawartej w pierwszym liście Św. Piotra, rozdział pierwszy, wiersz jedenasty. „JL” - iniciały Locke'a, które niekiedy znajdują się na końcu poszczególnych notatek. J. Locke, Adversaria Theologica 94, s. 19-33, [w:] idem, Writings on Religion..., s. 27.

104 W.M. Spellman, John Locke, Houndmills i dalsze 1997, s. 41.

105, „...) undeniable Proofs of his being the Messiah”. J. Locke, The Reasonableness..., s. 164. 
w swej prostocie. W czasie, gdy wzajemne oskarżenia o heterodoksję nie tylko były na porządku dziennym, ale posiadały także siłę publicznej dyskredytacji oskarżonej osoby, Locke nie stronił od utrzymywania bliskich kontaktów z członkami radykalnych grup, wśród nich także i deistami ${ }^{106}$.

Locke'owski Bóg rozumu nie jest autonomicznym rozumem naturalnym. Nie jest nim nie dlatego, iż nie może uwolnić ${ }^{107}$ się od pozytywnego prawa bożego, wręcz przeciwnie, nie poszukuje autonomii i oderwania się od objawienia, gdyż nie ma takiego zamiaru. Bóg nie jest dla Locke’a podmiotem, któremu z konieczności trzeba zrobić miejsce w swej konstrukcji politycznej czy filozoficznej. Biorąc pod uwagę całokształt dzieła Locke’a, trudno jest sobie wyobrazić, by - podobnie jak Hugo Grocjusz (1583-1645) $)^{108}$ - chociażby w teorii eksperymentował z myślą niebytu bożego. W Liście o tolerancji Locke pisze, iż ,w następstwie negacji Boga, już bodaj w samej myśli, (...) wszystko traci swą wartość"109.

Zagłębianie się w złożony świat duchowy Locke’a przybliża wiarę brytyjskiego myśliciela, umożliwiając tym samym zrozumienie teologii stojącej za podstawami praw człowieka, ujętymi w art. 1 Deklaracji Praw Wirginii. V. Nuovo uważa Locke’a za jednego z ,głównych twórców nowoczesnego, liberalnego chrześcijaństwa" ${ }^{110}$. Mimo rozwiniętego wolnomyślicielstwa w kwestiach teologicznych, Locke mieścił się jeszcze w ramach chrześcijaństwa anglikańskiego. Na pewno nie są to przemyślenia tożsame z ortodoksyjnym skrzydłem siedemnastowiecznego anglikanizmu. W całości zdecydowanie bliżej im do tolerancyjnych poglądów latitudinarian. Latitudinarianami nazywano od czasów restauracji Stuartów część duchowieństwa Kościoła anglikańskiego, tolerancyjną wobec innych nurtów chrześcijaństwa i propagującą rozumność wiary chrześcijańskiej.

V. Celem niniejszego artykułu było zbadanie powiązań podstaw praw człowieka, zawartych w pierwszym półzdaniu pierwszego artykułu Deklaracji Praw Wirginii, z chrześcijańskimi koncepcjami w myśli Johna Locke’a. Treść wszystkich czterech podstaw praw człowieka okazała się być nierozłącznie powiązana z chrześcijańskimi ideami locke’owskiej myśli. Nierozłącznie, ponieważ one są treścią owych idei. Prawa człowieka są uniwersalne, przy-

106 W.M. Spellman, op. cit., s. 29, 58, 73.

107 Nina Gładziuk przytacza współczesnych Locke’owi, którzy ,pragnąc wypracować teorię prawa natury, poznawalnego wyłącznie za pomocą rozumu naturalnego, nie mogą się uwolnić od Wielkiego Prawodawcy, czyli od pozytywnego prawa Bożego”. Nina Gładziuk, op. cit., s. 288.

108 Hugo Grocjusz w swojej koncepcji prawa naturalnego ustanowił tezę, iż nawet gdyby Bóg nie istniał, prawo naturalne nie przestałoby obowiązywać człowieka. H. Grocjusz, O prawie wojny i pokoju, Prolegomena, § 11, tłum. R. Bierzanek, Warszawa 1957.

109 J. Locke, List o tolerancji..., s. 55.

110 ,(...) principal founder of modern liberal Christianity”. V. Nuovo, Christianity, Antiquity and Enlightment, Interpretations of Locke, Dordrecht i dalsze 2011, s. 98. 
sługują bowiem każdej istocie posiadającej potencjalną możność poznania Boga. Są prawami przyrodzonymi, gdyż człowiek posiada je z natury, to znaczy z faktu bycia stworzonym przez Boga. Należą się każdemu człowiekowi w równy sposób, albowiem Bóg nie wyróżniał nikogo w akcie stworzenia.

Nie można ani samego siebie, ani innego człowieka pozbawić tych praw, gdyż pozbywając się niezbywalnych uprawnień, bezprawnie naruszona zostalaby własność Boga.

George Mason przeniósł locke'owską treść czterech podstaw praw człowieka do Deklaracji Praw Wirginii. Niewiadomą pozostanie, jak dalece Mason był świadomy nie tylko ich teistycznego, ale i wyraźnie chrześcijańskiego wymiaru. Uwzględniając jego własną wiarę, można przyjąć za możliwą podstawową przychylność ich zawartości ideowej. Nie ma podstaw do przyjęcia założenia, iż Mason, świadomy locke'owskich wywodów, negowałby lub próbowałby przeinaczyć ich znaczenie.

Rozumienie podstaw praw człowieka, zawartych w pierwszym artykule Deklaracji Praw Wirginii, jak i myśl Locke'a w całości spotkał podobny los, czyli oderwanie od ukierunkowanego na Boga świata ich autora. Idee Locke'a były przedmiotem wielokrotnych refleksji przez następne stulecia. Można przypuszczać, iż uznałby on to za sukces nieporównywalny z wiecznością, ,(...) ponieważ teraźniejsze położenie człowieka nie zawiera w sobie niczego takiego, co by w jakiś sposób można było porównać z przyszłym i wiecznym"111.

\section{BIBLIOGRAFIA}

Aylmer G.E., 1603-1689, The Struggle for the Constitution, England in the Seventeenth Century, London 1963.

Broadwater J., George Mason Forgotten Founder, University of North Carolina 2006.

Buckley T.E., Patrick Henry, Religious Liberty, and the Search for Civic Virtue, s. 125-144, [w]: The Forgotten Founders on Religion and Public Life, wyd. D. Dreisbach, M. Hall, J. Morrison, Notre Dame 2009.

Copeland P., MacMaster R., The Five George Masons, Charlottesvilles 1975.

Davidow R.P., Introduction, s. 1-31, [w:] Natural Rights and Natural Law: The Legacy of George Mason, wyd. R.P. Davidow, Fairfax 1986.

Dreisbach D.L., Famous Founders and Forgotten Foudners. What's the Difference, and Does the Difference Matter?, s. 1-25, [w:] The Forgotten Founderson Religion and Public Life, wyd. D. Dreisbach, M. Hall, J. Morrison, Notre Dame 2009.

Gładziuk N., Druga Babel, Antynomie siedemnastowiecznej angielskiej myśli politycznej, Warszawa 2005.

111 J. Locke, List o tolerancji..., s. 48. 
Piotr Tomczyk

Grocjusz H., O prawie wojny i pokoju, Prolegomena, § 11, tłum. R. Bierzanek, Warszawa 1957.

Holmes D.L., The Faith of the Founding Fathers, Oxford i dalsze 2006.

Hutson J., The Bill of Rights and the American Revolutionary experience, s. 62-97, [w:] A culture of rights. The Bill of Rights in philosophy, politics, and law 1791-1991, wyd. M.J. Lacey, K. Haakonssen, Cambridge 1992.

Kühnhardt L., Die Universalität der Menschenrechte, Bundeszentrale für politische Bidung, Bonn 1987.

Kędzia Z., Prawa i Obowiązki Obywateli, wybór źródeł, Wrocław 1978.

Locke J., Adversaria Theologica 94, s. 19-33, [w:] idem, Writings on Religion, wyd. V. Nuovo, Oxford 2002.

Locke J., A Vindication of the Reasonableness of Christianity, s. 211-225, [w:] idem, Writings on Religion, wyd. V. Nuovo, Oxford 2002.

Locke J., Dwa traktaty o rzadzie, tłum. Z. Rau, Warszawa 1992.

Locke J., List o tolerancji, tłum. L. Joachimowicz, red. Z. Ogonowski, Warszawa 1963.

Locke J., Peccatum originale i Homo ante et post lapsum, s. 229-231, [w:] idem, Writings on Religion, wyd. V. Nuovo, Oxford 2002.

Locke J., Questions concerning the Law of Nature, New York 1990.

Locke J., The Reasonableness of Christianity, as delivered in the Scriptures, s. 85-210, [w:] idem, Writings on Religion, wyd. V. Nuovo, Oxford 2002.

Mason R.C., George Mason of Virginia, Citizen, Statesman, Philosopher, O.A. Morgner, New York 1919.

Mayer H., A Son of Thunder, Patrick Henry and The American Republic, Franklin Watts, New York 1986.

McDonald F., Novus Ordo Seclorum, The Intellectual Origins of the Constitution, Lawrence 1985.

Miller Hill H., George Mason Constitutionalist, P. Smith, Gloucester 1966.

Miller Hill H., George Mason, Gentleman Revolutionary, University of North Carolina Press 1975.

Murrin J. M., Can Liberals be Patriots? Natural Right, Virtue, and Moral Sense in the America of George Mason and Thomas Jefferson, s. 35-65, [w:] Natural Rights and Natural Law: The Legacy of George Mason, wyd. R.P. Davidow, Fairfax 1986.

Motyka K., Prawa Człowieka, Wprowadzenie, Wybór Źródeł, Lublin 2004.

Nuovo V., Christianity, Antiquity and Enlightment, Interpretations of Locke, Dordrecht i dalsze 2011.

Ogonowski Z., Locke, Warszawa 1972.

Patterson O., Freiheit, Sklaverei und die moderne Konstruktion der Rechte, s. 164-218, [w:] Die kulturellen Werte Europas, wyd. H. Joas, K. Wiegandt, Frankfurt am Main 2006.

Rau Z., Umowa spoleczna w doktrynie Johna Locke'a, s. 127-151, [w:] Umowa społeczna i jej krytycy w myśli politycznej i prawnej, red. Z. Rau, M. Chmielinski, Warszawa 2010.

Rowland Mason K., The Life of George Mason, 1725-1792, Volume I, New York 1892. 
Ryan A., The British, the Americans, and rights, s. 366-439, [w:] A culture of rights.

The Bill of Rights in philosophy, politics, and law 1791-1991, wyd. M.J. Lacey,

K. Haakonssen, Cambridge 1992.

Spellman W. M., John Locke, Houndmills i dalsze 1997.

Strauss L., Prawo Naturalne w Świetle Historii, tłum. T. Górski, Warszawa 1969.

The Papers of George Mason, 1725-1792, Volume 1, wyd. R.A. Rutland, University of North Carolina Press 1970.

The Roots of The Bill of Rights, An illustrated Source Book of American Freedom, Volume 2, wyd. Bernard Schwartz, New York 1980.

\author{
FOUNDATIONS OF HUMAN RIGHTS \\ IN THE VIRGINIA DECLARATION OF RIGHTS IN VIEW \\ OF JOHN LOCKE'S PHILOSOPHY
}

\begin{abstract}
Summary
The aim of the article is to describe the four foundations of human rights (universality, naturalness, equality and inalienability) which are, according to the author, to be found in the first half of Section 1 of the Virginia Declaration of Rights from 1776. After an introduction to the document itself, George Mason, the author of the Virginia Declaration of Rights, is introduced with special attention paid to his religious beliefs. Then the foundations of human rights in the Virginia Declaration of Rights are discussed in detail from the perspective of John Locke's convictions. It turns out that the content of all four foundations is inseparably connected with Christian ideas of Locke's philosophy.
\end{abstract}

\title{
LES PRINCIPES FONDAMENTAUX DES DROITS DE L'HOMME DANS LA DÉCLARATION DES DROITS DE L'ÉTAT DE VIRGINIE, À LA LUMIĖRE DE LA PENSÉE DE JOHN LOCKE
}

\section{Résumé}

Le but de cet article est de décrire les quatre principes fondamentaux des droits de l'homme (universalité, inhérence, égalité et inaliénabilité) contenus - selon l'auteur - dans la première semi-sentence de l'art.1 de la Déclaration des droits de l'État de Virginie adoptée en 1776. Après la présentation du document, c'est George Mason, auteur de la Déclaration des droits de l'État de Virginie, qui est présenté. Cette partie de l'article met un accent particulier sur ses croyances religieuses. Ensuite, chacun des quatre principes fondamentaux des droits de l'homme contenus dans la Décla- 
ration des droits de l'État de Virginie est profondément décrit du point de vue des convictions de John Locke. Le contenu de tous les quatre principes fondamentaux des droits de l'homme se révèle être inextricablement lié à la conception chrétienne présente dans les idées de Locke. 